Vietnam Journal of Earth Sciences, 38(2), 217-230, DOI: 10.15625/0866-7187/38/2/8603

Vietnam Academy of Science and Technology
(VAST) Vietnam Journal of Earth Sciences
http://www.vjs.ac.vn/index.php/jse

\title{
Characteristics of marine environmental geochemistry from Ha Tinh to Quang Nam (60-100 m water depth)
}

\author{
Luong Le Huy*1, Mai Trong Nhuan², Tran Dang Quy², Hoang Van Tuan ${ }^{1}$, Quach Manh Dat ${ }^{3}$, \\ Nguyen Duc Hoai ${ }^{4}$, Nguyen Tai Tue ${ }^{2}$ \\ ${ }^{1}$ Sea and Island Research Center - VNU University of Science \\ ${ }^{2}$ Faculty of Geology - VNU University of Science \\ ${ }^{3}$ Vietnam National University Hanoi \\ ${ }^{4} \mathrm{VNU}$ University of Science \\ Received 8 May 2016. Accepted 28 June 2016
}

\section{ABSTRACT}

The aim of this study is to elucidate the characteristics of marine environmental geochemistry from Ha Tinh Quang Nam (60-100m water depth) based on analysis of geochemical parameters of seawater and surface sediments. Surface sediments that are high in absorbed capacity of toxic substances mainly accumulated in northern study area. Seawater dominantly characterized by weak alkaline-weak oxidation and contained biodegradable organic materials. Almost anion and chemical element concentrations in seawater tended to decrease with depth, with an exception for $\mathrm{SO}_{4}{ }^{2-}, \mathrm{Br}^{-}, \mathrm{I}^{-}$concentrations that had an opposite trend, increasing with depth and $\mathrm{B}, \mathrm{Hg}$ concentrations displayed a complex variation. Sedimentary environments were highly predominant by weak alkaline-strong oxidizing features and carbonate-rich materials. Concentrations of anions and chemical elements tended to be higher in central area in comparison to northern and southern regions, and positively correlated with fine sediment compositions. Organochlorine pesticides (OCPs) concentration decreased with sediment depth, whilst polychlorinated biphenyls (PCBs) concentration had no clear trend. The organic material, heavy metal, OCPs and PCBs concentrations in seawater and sediments were all lower than environmental standards. The present results have provided important baseline data for monitoring marine environment quality and protecting the marine ecosystem of Ha Tinh - Quang Nam Sea.

Keywords: Marine environmental geochemistry; Seawater; Marine sediment; Ha Tinh, Quang Nam.

(C)2016 Vietnam Academy of Science and Technology

\section{Introduction}

Marine resources play important roles for socio-economic development. However, the high development of socio-economic development on the mainland often causes many

*Corresponding author, Email: huyll.dktdmt@gmail.com impacts on the marine environment such as degradation of seawater and marine sediment environments (Helsinki Commission, 2004; Naser, 2013, Valavanidis and Vlachogianni, 2010). Marine pollution by heavy metals and organic components (i.e., OCPs, PCBs) has been critical issues due to the toxicity, persis- 
tent and bioaccumulation in trophic levels of the food chain (Aderinola et al., 2009; Esslemont, 2000; Vizzini et al., 2013). Heavy metals can be released from sediments to seawater and vice versa due to the changing of environmental geochemistry. Therefore, study of the contamination of heavy metals and organic components in marine environments is necessary for protecting the marine ecosystems. Many researchers have been conducted to study the marine geoenvironment, for example, origin of organic matters in seawater and sediments (Hedges and Clark, 1988) and geochemical characteristics (Glasby and Schulk, 1999). Recently, some environmental geochemistry researches have been conducted to assess the seawater and marine sediment quality, particularly the trace element contaminations in the nearshore region (Addo et al., 2011; Anderinola et al., 2009; Buccolieri et al., 2006; Carman et al., 2007) and coastal gulfs (Wang et al., 2010; Majer et al., 2014).

In Vietnam, environmental geochemistry researches have been integrated in several basic marine geological research programs (Nguyen, 1999; Pham, 2009; Tran, 2004; Vu, 2004). However, the marine environmental geochemistry of Ha Tinh - Quang Nam (60$100 \mathrm{~m}$ water depth) has not been reported so far. Therefore, the purposes of the present study are to examine the marine environmental geochemistry characteristics of seawater and marine sediments by analyzing the sediment grain sizes, $\mathrm{pH}$, Eh, heavy metals, persistent organic pollutants (polychlorinated biphenyls (PCBs) and organochlorine pesticides (OCPs), and other environmental parameters. The results from the present study will provide important baseline data for assessing the status quo of and monitoring the marine environmental quality in the future.

\section{Materials and Methods}

\subsection{Study area}

The study area is located in Ha Tinh Quang Nam Sea (60-100 m water depth), encompassing by depth contours of $60 \mathrm{~m}$ and
$100 \mathrm{~m}$, respectively (Figure 1). The marine environments of the study area receive freshwater flows and materials from the mainland by several large estuaries, including Han River estuary, Thuan An estuary, Nhat Le estuary, Viet estuary, Tung estuary, Dai estuary and Gianh estuary. The main human activities in this sea include urban development, fishing and marine transportation, which can have some impacts on marine environments. The coastal zone of the study area concentrates many large cities and industrial zones such as Dong Hoi, Hue and Da Nang cities, and Vung Ang and Chan May economic zones. Thus, the marine environments of the study area could be impacted by domestic and industrial sewages from above economic zones and cities. Moreover, the coastline of the study area has a large seaport system, which includes Vung Ang, Chan May, $\mathrm{Da}$ Nang international seaports. Additionally, the marine transportation has highly dense maritime routes of both national and international levels. Thus, the study area is highly sensitive with oil-spills from marine transportation and wrecks. Recent report showed that the study area was impacted by 14 serious oil-spills in the period from 2004-2012. The oil-spills caused a contamination of seawater by oils and impacts on the aquaculture and tourism on coastal areas (http://www.songthu.-com.vn).

Seawater temperature ranges from 28$30{ }^{\circ} \mathrm{C}$ and $22-25^{\circ} \mathrm{C}$ in the summer and winter, respectively. Sea waves in this area are controlled by monsoon and storms. In which, southeast waves are often stable and higher intensity than northwest waves. The largest waves with height from 6-7 $\mathrm{m}$ have been observed offshore of the study area.

The tides from Deo Ngang - Son Tra are very complicated by changing tidal regime four times per month: mixed diurnal tide, mixed semi - diurnal tide, diurnal tide and then repeated mixed semi - diurnal tide. Tides from from Son Tra - Quang Nam are mixed semi-diurnal tide. The sea currents from $\mathrm{Ha}$ Tinh - Deo Ngang annually flow following a 
Vietnam Journal of Earth Sciences, 38(2), 217-230

direction from the northeast to southwest with flow velocity from $25-50 \mathrm{~cm} / \mathrm{s}$. From Deo Ngang - Son Tra, the sea currents in both winter and summer have a direction from north to south and flow velocity varies by shoreline geomorphology. From Son Tra Quang Nam, the sea currents have a direction to the southwest in the period from October to April, and the rest of the year flow toward the northwest. The flow velocity of sea currents is $10-25 \mathrm{~cm} /$ year in summer and higher in winter, being $50-70 \mathrm{~cm} / \mathrm{s}$.

\subsection{Fieldwork and sampling}

The present study was conducted in $\mathrm{Ha}$ Tinh - Quang Nam Sea (60-100 m water depth) from April to July, 2012. A total of
1,341 sampling sites were surveyed and designed for collecting seawater and marine sediment samples (Figure 1). Seawater samples were collected from 804 sites, using a niskin bottle from three deep layers (surface, middle and bottom layer). Rich fine-grained sediment samples were collected from 465 sites for $\mathrm{pH}$, Eh analysis; 165 sites for cation exchange, iron ions, and carbonate analysis; 524 sites for elemental analysis; 1,093 sites for grain size analysis; and 402 sites for PCBs and OCPs. Sediment samples were collected by using an ocean grab sampler and a gravity corer. All samples were immediately kept on ice in cool boxes. The samples were then transported to laboratory for processing and analyzing at VNU University of Science and Institute of Industrial Chemistry.

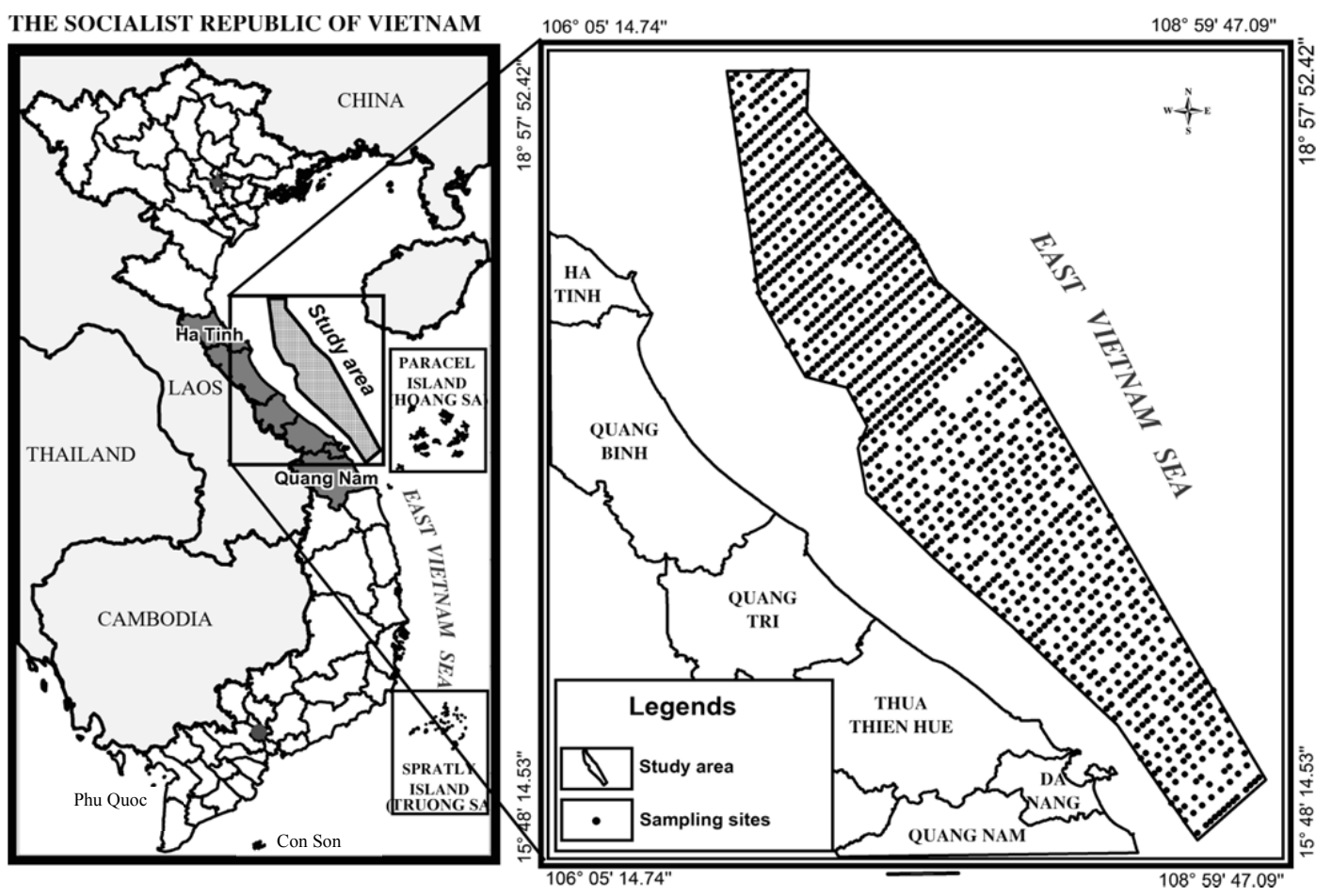

Figure 1. Map shows the location of Ha Tinh - Quang Nam Sea (60-100 m water depth) and sampling sites

\subsection{Sample analysis}

In the laboratory, Eh, $\mathrm{pH}$ and salinity of seawater samples were measured using a $\mathrm{pH}$,
$\mathrm{Eh}$, and salinity meter, respectively. The $\mathrm{Mn}$, $\mathrm{B}, \mathrm{Br}, \mathrm{I}, \mathrm{PO}_{4}^{3-}, \mathrm{NO}_{3}^{-}, \mathrm{SO}_{4}{ }^{2-}$ concentrations were determined using colorimetric methods. Total organic carbon (TOC) was measured 
using Knop method. The $\mathrm{K}, \mathrm{Na}, \mathrm{Cu}, \mathrm{Pb}, \mathrm{Zn}$, $\mathrm{Sb}$, As, $\mathrm{Hg}$ concentrations were analyzed using an atomic absorption spectroscopy (Perking Elmer AA 800). The analytical accuracy and precision were evaluated by comparing the analyzed results with reference materials following a guideline of the Ministry of Natural resources and Environment (MONRE, 2011). The OCPs and PCBs concentrations were Soxhlet extracted and analyzed using an Agilent Technology 7890 gas chromatograph (GC) interfaced with a high resolution mass spectrometer (HRMS). Similar to element analysis, the accuracy and precision organic compound analysis were assessed following the guideline of MONRE (2011). The sediment grain size composition was measured by both sieve and pipette methods.

\subsection{Statistical analysis}

The analytical results are statistically processed using a statistical software SPSS. Talasofil coefficient (Ta) and concentration factor (Td) are used to evaluate the concentration level of chemical elements in the seawater and marine sediments, respectively. Both the Ta and Td were calculated by a ratio of mean concentration of the chemical element and its concentration in the world mean concentration. Spatial variation of the geochemical parameters is presented using MapInfo software.

\section{Results and Discussion}

\subsection{Characteristics of surface sediments}

The study area has many sediment types, being fine to coarse grain sizes. According to the absorbed capacities of sediments to toxic substances, surface sediments can be divided into 3 groups (Figure 2): The sediments with low absorbed capacity to toxic substances are composed less than $20 \%$ of the fine-grained fraction, and the main components are sand and gravel. The total sandy gravel and TOC are $87.34 \%$ and $0.92 \%$, respectively. This sediment type distributes a small area within 60-65 meter in depth. The sediments with medium absorbed capacity to toxic substances have proportions of fine-grained fraction ranging from 20 to $60 \%$, being sandy mud. This sediment type distributes in a small area in the north and a sizable strip in the south. The main components of this group include $19.1 \pm 9.32 \%$ mud, $25 \pm 10.83 \%$ silt, $53.56 \pm$ $10.21 \%$ sand and $0.87 \pm 0.23 \%$ TOC. The sediments with high absorbed capacity to toxic substances have fine-grained fraction $>60 \%$, distributing mainly in the northern study area. The main compositions of this sediment group include mud, muddy sand and clay. The main components are $34.66 \pm 19.13 \%$ clay, 52.85 $\pm 23.15 \%$ silt, $12.41 \pm 11 \%$ sand and $0.8 \pm 0.21 \%$ TOC.

\subsection{Characteristics of marine environmen- tal geochemistry}

\subsubsection{Seawater environment}

Seawater salinity in the study area was $32.2 \%$ and tended to slightly increase from the surface to bottom water column and slightly to decrease towards the south. Results indicated that seabed topography of the northern area was more gently steep slope that made the northern sampling sites with the same depth located at more offshore and less effect by freshwater flows from main land in comparison to the southern sampling sites. Additionally, the southern part of the study area is received the flows of several relative big estuaries, including Dien Huong, Tu Hien, Thuan An, Dai estuaries. Means of $\mathrm{pH}$ and Eh parameters of seawater were 8.26 and $117.5 \mathrm{mV}$, respectively and tended to less vary with depth and horizontal space. This pattern indicated that seawater can be categorized as alkaline-weak oxidation. The concentration ranges of $\mathrm{COD}$ and $\mathrm{BOD}_{5}$ were 1.60-3.76 mg/l and 1.23-2.10 mg/l, respectively. The little difference between 
Vietnam Journal of Earth Sciences, 38(2), 217-230

$\mathrm{COD}$ and $\mathrm{BOD}_{5}$ indicated that the organic matter content in seawater was composed mainly by bio-degradable organic materials. Thus, seawater environment from Ha Tinh -
Quang Nam (60-100 m depth water) was less influenced by freshwater flows from main lands in the northern areas and contained mainly bio-degradable organic materials.

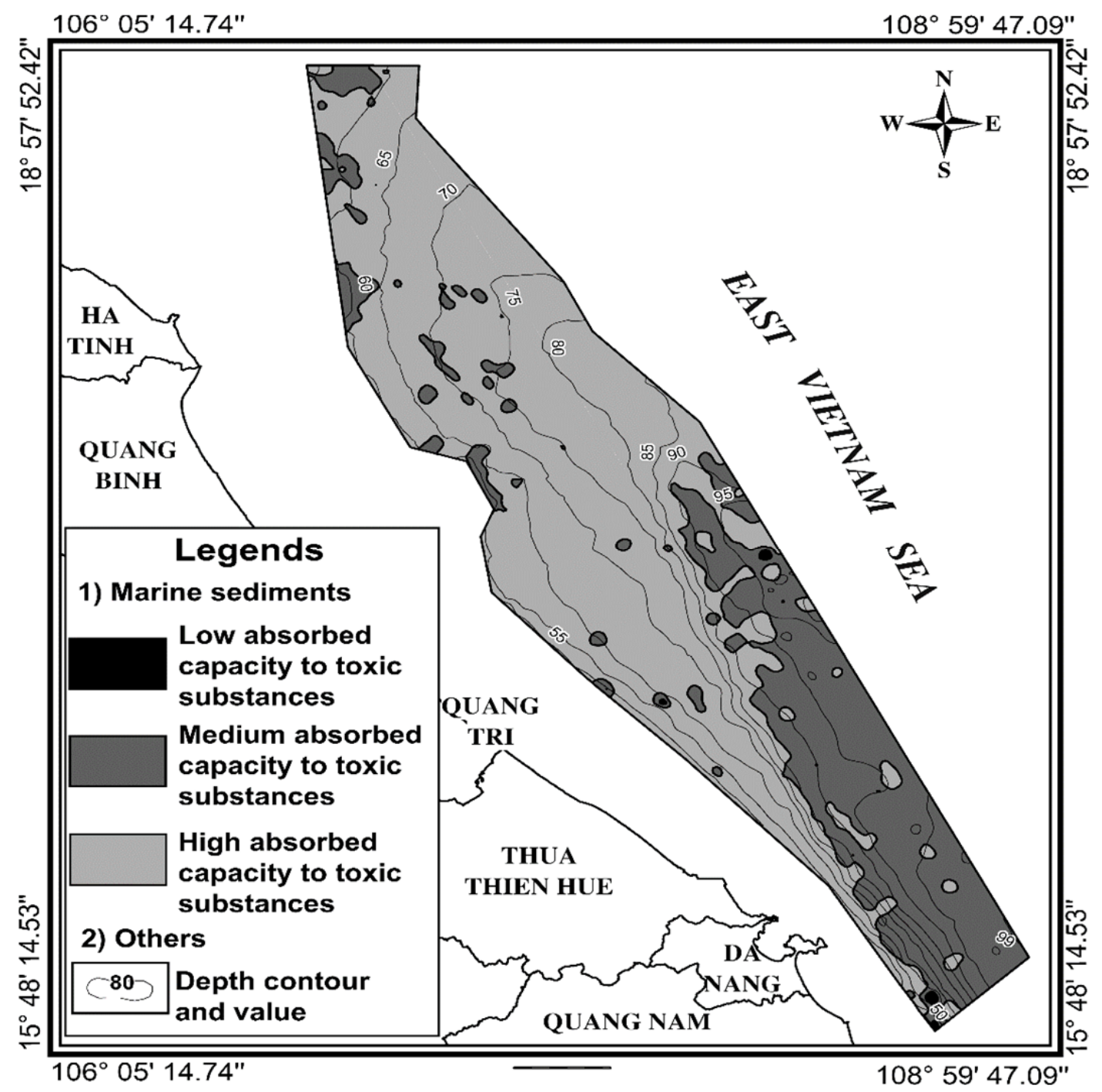

Figure 2. Spatial distribution of surficial sediments in Ha Tinh - Quang Nam Sea (60-100 m water depth)

The major anions $\mathrm{SO}_{4}{ }^{2-}$ and $\mathrm{NO}_{3}{ }^{-}$evenly distributed in the seawater of the study area with the variation coefficients were 7.0 and $2.6 \%$, respectively. The average concentration of $\mathrm{SO}_{4}{ }^{2-}$ was $2,447.9 \mathrm{mg} / \mathrm{l}$ and was higher than that in seawater from Tra Co - Son Tra region $(2,374.9 \mathrm{mg} / \mathrm{l})$ and tended to increase with depth. The average concentration of $\mathrm{NO}_{3}{ }^{-}$was $0.595 \mathrm{mg} / \mathrm{l}$, being lower than that in seawater from Tra Co - 
Son Tra region $(0.82 \mathrm{mg} / \mathrm{l})$ and tended to decrease with depth (Mai, 2011).

The mean concentration, the variation coefficient and the Ta of selected elements in seawater from Ha Tinh - Quang Nam (60100 meter depth) is shown in Table 1. The Ta of $\mathrm{Mg}, \mathrm{Sb}, \mathrm{As}, \mathrm{I}, \mathrm{B}$ and $\mathrm{Br}$ were $<1$, classifying as less concentrated elements in seawater. The variation coefficients of these elements ranged from $2.0-12.0 \%$, indicating that they evenly distributed in the seawater (Figure 3). Concentrations of $\mathrm{Mg}, \mathrm{Sb}$ and $\mathrm{As}$ tended to decrease with depth. But, the concentrations of I and $\mathrm{Br}$ tended to increase with the depth. Concentration of B displayed an unclearly trend, being the highest and lowest in the mid-dle and surface layer, respectively (Table 1).

Table 1. Statistical parametric concentration $(\mathrm{mg} / \mathrm{l})$ and Talasofil coefficient $(\mathrm{Ta})$ of selected elements in seawater from Ha Tinh - Quang Nam Sea $(60-100$ m water depth) $(\mathrm{n}=804)$

\begin{tabular}{|c|c|c|c|c|c|c|}
\hline & $\mathrm{Ctb}(\mathrm{tm})$ & $\mathrm{Ctb}(\operatorname{tg})$ & $\mathrm{Ctb}(\mathrm{td})$ & $\mathrm{Ctb}$ & V (\%) & $\overline{\mathrm{Ta}}$ \\
\hline $\mathrm{Mg}$ & $1,323.5$ & $1,308.6$ & $1,287.1$ & $1,306.4$ & 12.0 & 0.96 \\
\hline $\mathrm{Sb}$ & 0.000435 & 0.000426 & 0.000424 & 0.000428 & 5.9 & 0.96 \\
\hline As & 0.00309 & 0.00301 & 0.00296 & 0.00302 & 11.7 & 1 \\
\hline I & 0.0550 & 0.0556 & 0.0560 & 0.0550 & 5.5 & 0.85 \\
\hline B & 4.078 & 4.100 & 4.094 & 4.091 & 5.2 & 0.84 \\
\hline $\mathrm{Br}$ & 59.24 & 59.30 & 59.43 & 59.32 & 2.0 & 0.85 \\
\hline $\mathrm{Mn}$ & 0.00273 & 0.00263 & 0.00249 & 0.00262 & 39.6 & 1.3 \\
\hline $\mathrm{Cu}$ & 0.00347 & 0.00341 & 0.00328 & 0.00339 & 41.3 & 1.1 \\
\hline $\mathrm{Zn}$ & 0.0154 & 0.0146 & 0.0144 & 0.0148 & 14.5 & 1.5 \\
\hline $\mathrm{Cd}$ & 0.000177 & 0.000174 & 0.000164 & 0.000172 & 43.0 & 1.7 \\
\hline $\mathrm{Hg}$ & 0.000038 & 0.000035 & 0.000036 & 0.000036 & 36.6 & 1.2 \\
\hline $\mathrm{Pb}$ & 0.000260 & 0.000253 & 0.000250 & 0.000255 & 29.7 & 8.5 \\
\hline
\end{tabular}

Note: $\mathrm{Ctb}(\mathrm{tm}), \mathrm{Ctb}(\mathrm{tg}), \mathrm{Ctb}(\mathrm{td})$ and $\mathrm{Ctb}$ are the average concentration of surface, middle, bottom layer and whole area, respectively; $\mathrm{V}$ is variation coefficient; Ta is Talasofil coefficient

The $\mathrm{Ta}$ of $\mathrm{Mn}, \mathrm{Cu}, \mathrm{Zn}, \mathrm{Cd}, \mathrm{Hg}$ ranged from 1 to 2 , indicating that they were weak concentrated elements in seawater. In which, $\mathrm{Zn}$ distributed very uniform with the variation coefficient of $14.5 \%$; Mn, $\mathrm{Hg}$ evenly distributed with respective variation coefficients of 39.6 and $36.6 \%$ and $\mathrm{Cu}, \mathrm{Cd}$ distributed relatively uniform with the variation coefficients of 41.3 and $43.0 \%$. Concentrations of $\mathrm{Mn}, \mathrm{Cu}$ and $\mathrm{Cd}$ decreased with the water depth. The variation of $\mathrm{Hg}$ concentration was an unclearly trend with the highest concentration within the surface layer and the lowest concentration at the middle layer.

The $\mathrm{Ta}$ of $\mathrm{Pb}$ was 8.5 , indicating for the strong concentration level in seawater. Concentration of $\mathrm{Pb}$ evenly distributed in seawater with the variation coefficient of $29.73 \%$ (Figure 3). The concentration of $\mathrm{Pb}$ slightly decreased with depth, being $0.26 .10^{-3} \mathrm{mg} / \mathrm{l}$, $0.253 .10^{-3} \mathrm{mg} / \mathrm{l}$ and $0.25 .10^{-3} \mathrm{mg} / \mathrm{l}$ for the surface, middle and bottom layer, respectively.

\subsubsection{Marine sediment environment}

Means of $\mathrm{pH}$ and $\mathrm{Eh}$ in sediments were 8.19 and $105.0 \mathrm{mV}$, respectively. The $\mathrm{pH}$ and Eh ranged from 7.15-8.95 and from -183 to $200 \mathrm{mV}$, respectively. The geochemical environment of sediments was relatively complex and could be divided into weak alkaline-strong oxidation, weak alkaline-weak oxidation; weak alkaline-strong reduction. In which, weak alkaline-strong oxidation environment was the most dominant. 
Vietnam Journal of Earth Sciences, 38(2), 217-230
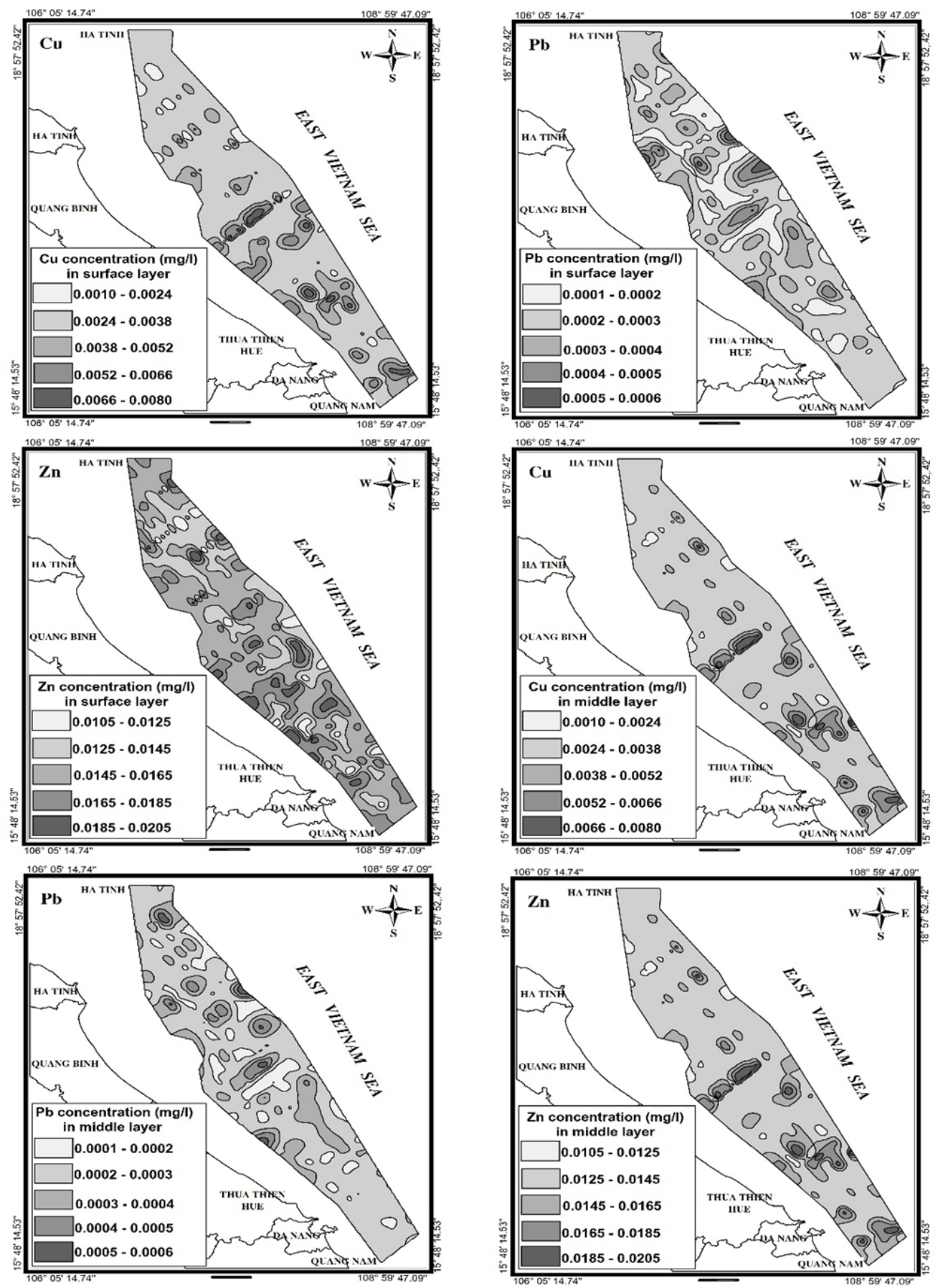

Figure 3. Spatial distribution of selected metal concentrations in different seawater layers from Ha Tinh Quang Nam (60-100 m water depth) 


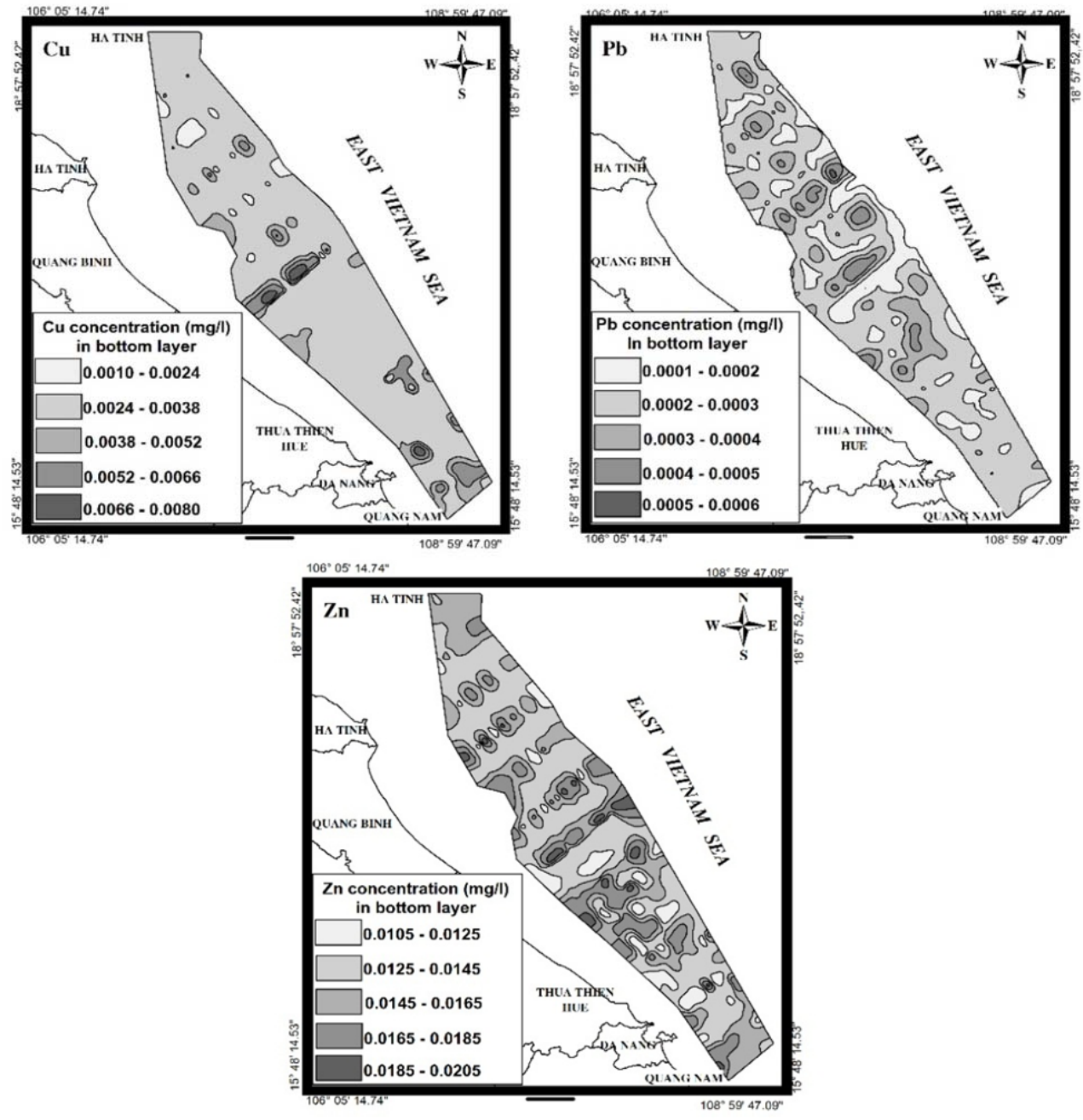

Figure 3.

The major anions had different distribution characteristics in the marine sediment (Table 2). $\mathrm{SO}_{4}{ }^{2-}$ and $\mathrm{PO}_{4}{ }^{3-}$ displayed a highly uniform variation with the variation coefficients ranged from 11.7 $13.5 \% ; \mathrm{NO}_{3}^{-}$distributed evenly with the variation of $20.8 \%$ and $\mathrm{CO}_{3}{ }^{2-}$ unevenly distributed with the variation coefficient of $57.4 \% . \mathrm{SO}_{4}{ }^{2-}, \mathrm{PO}_{4}{ }^{3-}$ and $\mathrm{NO}_{3}{ }^{-}$concentrations tended to be higher in the central region of the research area and decreased towards the northern and southern regions. The decreasing gradient seemed to be faster in the south. The concentrations of major anions positively correlated with fine-grained sediment fraction $(\mathrm{r}=0.42-0.46) . \mathrm{CO}_{3}{ }^{2-}$ concentration tended to be higher in the northern and southern regions, and lower in the central region of the study area. The $\mathrm{CO}_{3}{ }^{2-}$ concentration negatively correlated with the fine-grained sediment fraction $(\mathrm{r}=$ -0.3) (Table 2). Comparison to the marine sediments from Tra Co - Son Tra area, the concentrations of $\mathrm{SO}_{4}{ }^{2-}$ and $\mathrm{NO}_{3}{ }^{-}$were lower, but the concentrations of $\mathrm{PO}_{4}^{3-}$ and $\mathrm{CO}_{3}{ }^{2-}$ were relatively similar (Mai, 2011). 
Vietnam Journal of Earth Sciences, 38(2), 217-230

According to concentration factor (Td), the element concentrations in marine sediments can be divided into three groups as follows: less concentrated elements $(\mathrm{Td}<1)$ were $\mathrm{Mn}$, $\mathrm{Zn}, \mathrm{Pb}, \mathrm{Cu}, \mathrm{Sb}$ and $\mathrm{As}$; weak concentrated elements $(1<\mathrm{Td}<2)$ were $\mathrm{Hg}$ and $\mathrm{Pb}$; strong concentration elements $(\mathrm{Td} \geq 3)$ were $\mathrm{Br}$ and I. The element concentrations tended to increase in the central area and decrease towards the nothern and southern regions (Figure 4). The tendency of element concentrations was similar to the fine-grained size sediments, resulting the correlation coefficient between element concentrations and fine-grained size sediments ranged from 0.41-0.58 (Table 2). The variation coefficients of the heavy metals and halogen elements ranged from $12.7-29.3 \%$, indicating that they distributed highly uniform in marine sediments. The high concentration levels of $\mathrm{Br}$ and I could be explained by their high concentration in marine biological substances (i.e., phytoplankton, seaweeds). The distributing patterns of these elements in the present study were relative similar to those of Tra Co - Son Tra area (Mai, 2011).
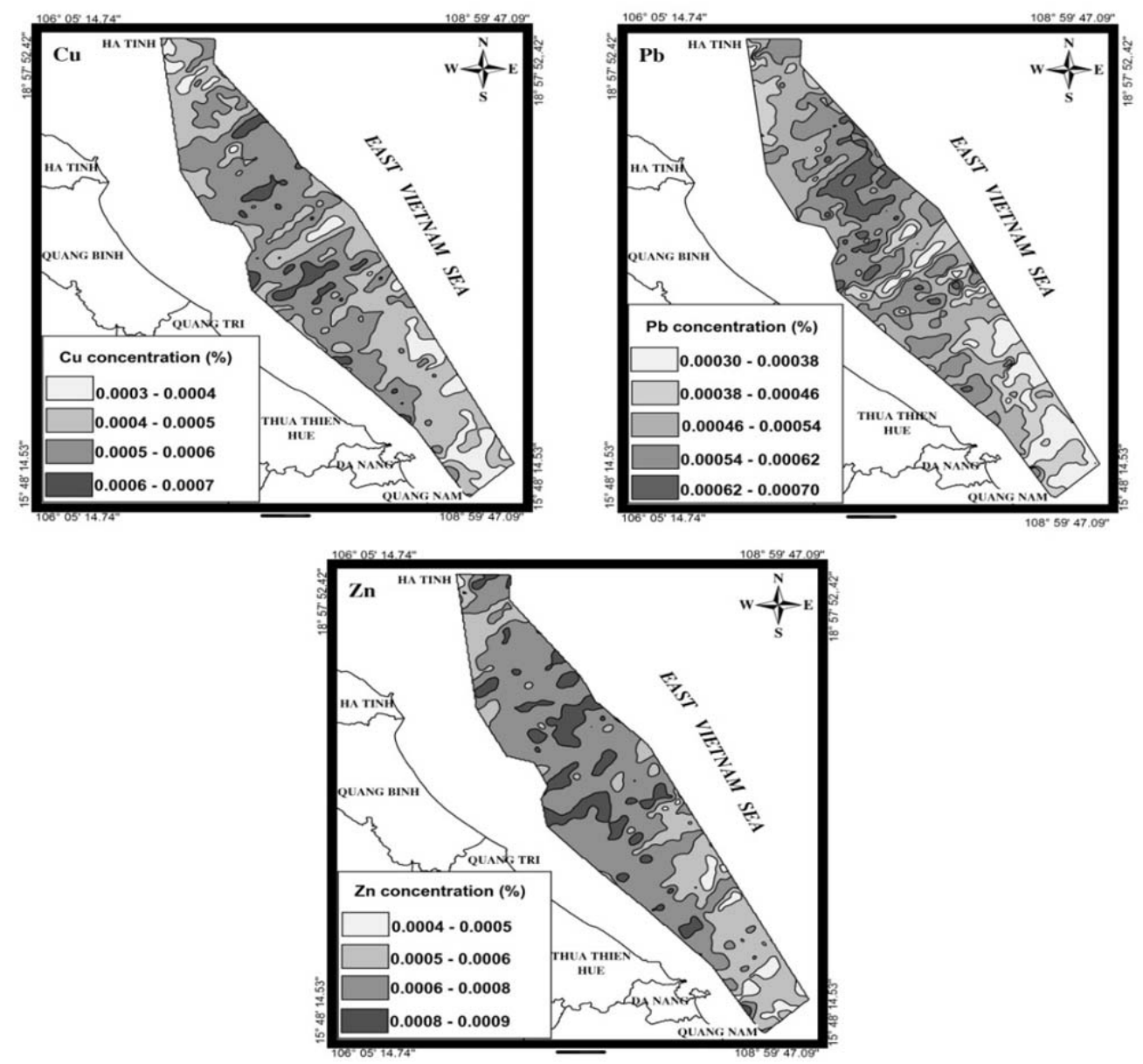

Figure 4. Spatial distribution of selected elements in marine sediments from Ha Tinh - Quang Nam Sea (60-100 m water depth) 
L. L. Huy, et al./Vietnam Journal of Earth Sciences 38 (2016)

Table 2. Statistical parametric concentration and $\mathrm{Td}$ coefficient of selected elements in marine sediments from Ha Tinh - Quang Nam (60-100 m water depth) $(n=524)$

\begin{tabular}{|c|c|c|c|c|c|c|c|c|}
\hline & Unit & Cmax & Cmin & Cmean & $\mathrm{V}(\%)$ & HLTBTG & $\mathrm{Td}$ & $\mathrm{r}$ \\
\hline $\mathrm{Mn}^{2+}$ & $\%$ & 0.053 & 0.023 & 0.037 & 16.7 & 0.085 & 0.43 & 0.44 \\
\hline $\mathrm{Zn}^{2+}$ & $10^{-3} \%$ & 0.87 & 0.43 & 0.69 & 14.3 & 2 & 0.35 & 0.58 \\
\hline $\mathrm{Pb}^{2+}$ & $10^{-3} \%$ & 0.69 & 0.39 & 0.54 & 12.7 & 2 & 0.27 & 0.56 \\
\hline $\mathrm{Cu}^{2+}$ & $10^{-3} \%$ & 0.69 & 0.32 & 0.49 & 14.8 & 4 & 0.12 & 0.52 \\
\hline $\mathrm{Sb}^{3+}$ & $10^{-3} \%$ & 0.046 & 0.02 & 0.032 & 17.6 & 0.14 & 0.23 & 0.49 \\
\hline $\mathrm{As}^{3+}$ & $10^{-3} \%$ & 0.14 & 0.05 & 0.08 & 22.8 & 0.1 & 0.82 & 0.41 \\
\hline $\mathrm{Hg}^{2+}$ & $10^{-3} \%$ & 0.0092 & 0.0028 & 0.0056 & 22.5 & 0.003 & 1.88 & 0.49 \\
\hline $\mathrm{SO}_{4}{ }^{2-}$ & $\%$ & 0.033 & 0.018 & 0.025 & 13.5 & & & 0.42 \\
\hline $\mathrm{PO}_{4}{ }^{3-}$ & $\%$ & 0.033 & 0.018 & 0.026 & 11.7 & & & 0.46 \\
\hline $\mathrm{NO}_{3}^{-}$ & $\%$ & 0.019 & 0.005 & 0.009 & 20.8 & & & 0.45 \\
\hline $\mathrm{CO}_{3}{ }^{2-}$ & $\%$ & 15.90 & 0 & 5.11 & 57.4 & & & -0.30 \\
\hline $\mathrm{B}^{-}$ & $10^{-3} \%$ & 5 & 1.4 & 3 & 26.5 & 2 & 1.51 & 0.55 \\
\hline $\mathrm{Br}^{-}$ & $10^{-3} \%$ & 6.8 & 1.9 & 3.7 & 27.1 & 0.6 & 6.2 & 0.55 \\
\hline $\mathrm{I}^{-}$ & $10^{-3} \%$ & 3.6 & 0.9 & 1.8 & 29.3 & 0.11 & 16.55 & 0.50 \\
\hline
\end{tabular}

Note: Cmax, Cmin, Cmean are the maximum, minimum, average concentration, respectively; $\mathrm{V}$ is variation coefficient; HLTBTG is the world average concentration; Td is concentration coefficient; $r$ is correlation coefficient with fine-grained size sediment fraction

The total concentration of PCBs ranged from $0.36-5.18 \mathrm{ng} / \mathrm{g}$ with an average of 2.78 $\mathrm{ng} / \mathrm{g}$. In which, the main congeners were 2,2',3,4,5,6'-hexachlorobiphenyl with an average concentration of $0.88 \mathrm{ng} / \mathrm{g}$; $2,2^{\prime}, 3,4,4^{\prime}, 5$-hexaclorobiphenyl with an average concentration of $1.02 \mathrm{ng} / \mathrm{g}$, total $6 \mathrm{Cl}$ with an average concentration of $1.99 \mathrm{ng} / \mathrm{g}$. Other congeners had lower concentration, ranging from 0-0.43 ng/g (Table 3, Fig. 5a).

The concentration of OCPs ranged from 0.03-0.39 $\mathrm{ng} / \mathrm{g}$. In which, the 44DDD and 44DDT congeners had the highest concentration, ranging from $0.005-0.13 \mathrm{ng} / \mathrm{g}$ and from $0.005-0.18 \mathrm{ng} / \mathrm{g}$, respectively. Other congener concentrations were lower, ranging from 0 $0.07 \mathrm{ng} / \mathrm{g}$ (Tables 4, Figure 5b).

Table 3. The PCB congener concentrations (ng/g) in marine sediments from Ha Tinh-Quang Nam (60-100m water depth) $(\mathrm{n}=402)$

\begin{tabular}{|c|c|c|c|}
\hline Congener & Cmin & Cmax & Cmean \\
\hline 2,4,4' - triclorobiphenyl & 0.05 & 0.28 & 0.12 \\
\hline $2,2^{\prime}, 5,5^{\prime}$ - tetraclorobiphenyl & 0.03 & 0.42 & 0.1 \\
\hline $2,2^{\prime}, 4,5,5^{\prime}$ - pentaclorobiphenyl & 0.06 & 0.35 & 0.21 \\
\hline $2,3,4,4$ ',5 - pentachlorobiphenyl & 0.07 & 0.34 & 0.28 \\
\hline $2,2^{\prime}, 3,4,5,6^{\prime}-$ hexachlorobiphenyl & 0.05 & 1.81 & 0.88 \\
\hline $2,2^{\prime}, 3,4,4$ ',5 - hexaclorobiphenyl & 0.05 & 1.72 & 1.02 \\
\hline $2,2^{\prime}, 3,4,4^{\prime}, 5,5^{\prime}$ - heptaclorobiphenyl & 0.01 & 0.13 & 0.03 \\
\hline Total $2 \mathrm{Cl}$ & 0.03 & 0.07 & 0.05 \\
\hline Total $3 \mathrm{Cl}$ & 0.06 & 0.9 & 0.14 \\
\hline Total $4 \mathrm{Cl}$ & 0.06 & 0.56 & 0.13 \\
\hline Total $5 \mathrm{Cl}$ & 0.09 & 0.93 & 0.43 \\
\hline Total $6 \mathrm{Cl}$ & 0.09 & 4.04 & 1.99 \\
\hline Total 7Cl & 0.02 & 0.7 & 0.06 \\
\hline Total $8 \mathrm{Cl}$ & 0.01 & 0.7 & 0.02 \\
\hline Total 9Cl & 0.01 & 0.09 & 0.02 \\
\hline Total $10 \mathrm{Cl}$ & 0 & 0 & 0 \\
\hline Total PCBs & 0.36 & 5.18 & 2.78 \\
\hline
\end{tabular}


Vietnam Journal of Earth Sciences, 38(2), 217-230
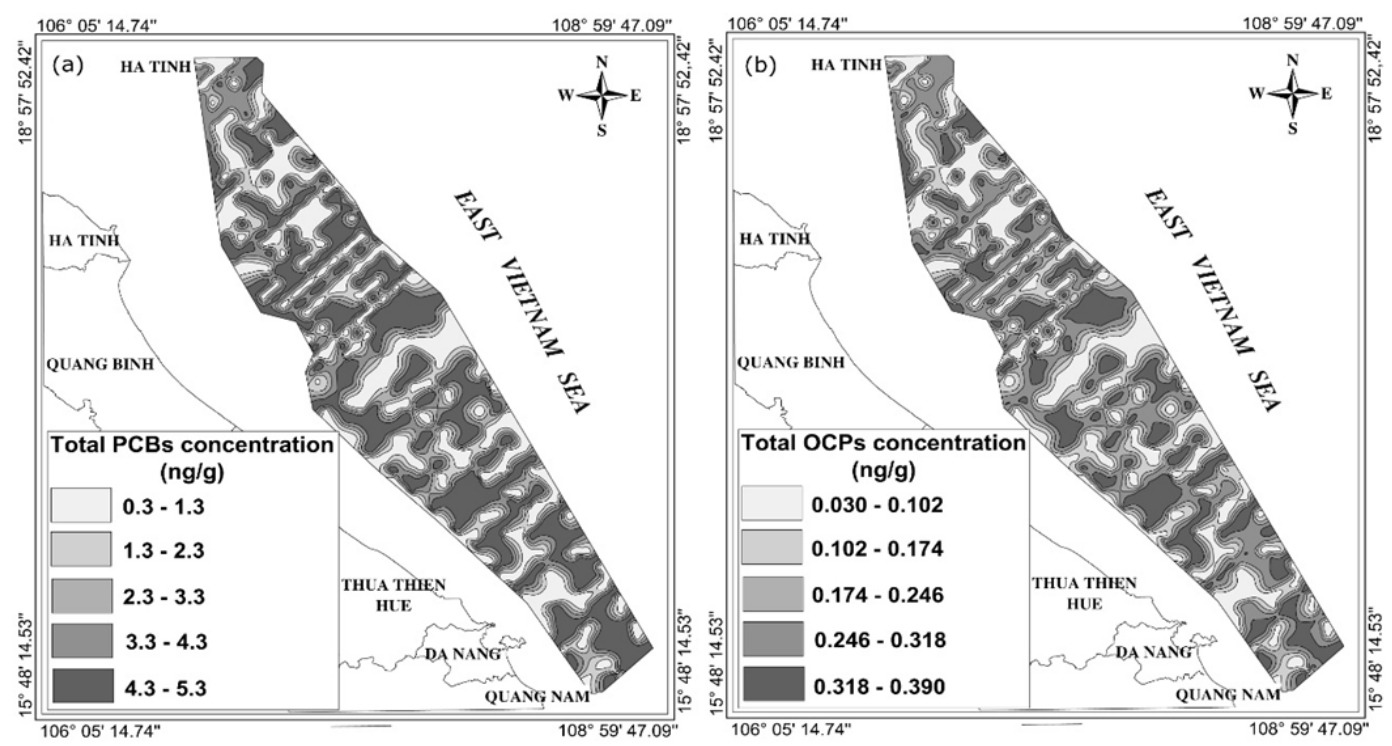

Figure 5. Spatial distribution of total OCPs and PCBs in surface sediment from Ha Tinh - Quang Nam Sea (60-100 m water depth)

Table 4. Concentration of OCP congeners ( $\mathrm{ng} / \mathrm{g})$ in marine sediments from Ha Tinh - Quang Nam (60-100 m water depth $)(n=402)$

\begin{tabular}{|c|c|c|c|c|c|c|c|}
\hline & $\alpha \mathrm{BHC}$ & $\gamma \mathrm{BHC}$ & $\beta \mathrm{BHC}$ & $\delta \mathrm{BHC}$ & 44DDE & 44DDD & 44DDT \\
\hline Cmin & 0 & 0.008 & 0 & 0.006 & 0.01 & 0.005 & 0.005 \\
\hline $\mathrm{Cmax}$ & 0.016 & 0.041 & 0.02 & 0.03 & 0.07 & 0.13 & 0.18 \\
\hline Cmean & 0.006 & 0.015 & 0.01 & 0.018 & 0.03 & 0.068 & 0.089 \\
\hline
\end{tabular}

Among 18 sampling sites were selected for analyzing PCBs and OCPs concentrations in different sediment layers. The total concentration of PCBs concentration was $5.5 \mathrm{ng} / \mathrm{g}$, being the highest in the sediment layers of 40 $80 \mathrm{~cm}$ in depth from offshore Cua Nhuong estuary and was $0.83 \mathrm{ng} / \mathrm{g}$, being the lowest in the sediment layers of $0-40 \mathrm{~cm}$ in depth from offshore from Ly Hoa estuary (Figure 6a1, b1).

The total concentration of OCPs was the highest in sediment layers of $80-100 \mathrm{~cm}$ in depth from offshore Cua Sot estuary, of 40-80 $\mathrm{cm}$ in depth from offshore Thuan An estuary with both mean of $0.46 \mathrm{ng} / \mathrm{g}$. In Cua Sot estuary, the congener concentration was 0.01 $\mathrm{ng} / \mathrm{g}(\gamma \mathrm{BHC}), 0.02 \mathrm{ng} / \mathrm{g}(\delta \mathrm{BHC}), 0.03 \mathrm{ng} / \mathrm{g}$ (44DDE), $0.14 \mathrm{ng} / \mathrm{g}$ (44DDD) và $0.26 \mathrm{ng} / \mathrm{g}$
(44DDT). In Thuan An estuary, the congener concentration was $0.01 \mathrm{ng} / \mathrm{g}(\gamma \mathrm{BHC}), 0.02$ $\mathrm{ng} / \mathrm{g}(\delta \mathrm{BHC}), 0.04 \mathrm{ng} / \mathrm{g}$ (44DDE), $0.15 \mathrm{ng} / \mathrm{g}$ (44DDD), and $0.24 \mathrm{ng} / \mathrm{g}$ (44DDT). The lowest total concentration of OCPs was 0.063 $\mathrm{ng} / \mathrm{g}$ in sediment layers of $0-40 \mathrm{~cm}$ in depth offshore the Lai headland. The congener concentrations were $0.016 \mathrm{ng} / \mathrm{g}(\gamma \mathrm{BHC}), 0.01$ $\mathrm{ng} / \mathrm{g}(\beta \mathrm{BHC}), 0.006 \mathrm{ng} / \mathrm{g}(\delta \mathrm{BHC}), 0.018 \mathrm{ng} / \mathrm{g}$ (44DDE), $0.08 \mathrm{ng} / \mathrm{g}$ (44DDT). Generally, the concentration of OCPs tended to increase with the sediment depth with an exception of sampling sites from the offshore (75-76 m water depth) Gianh estuary, Ly Hoa estuary (64-65 m water depth) and Le Thuy offshore (63-64 m water depth) tended to decrease with depth (Figure 6a2, b2). 
L. L. Huy, et al./Vietnam Journal of Earth Sciences 38 (2016)
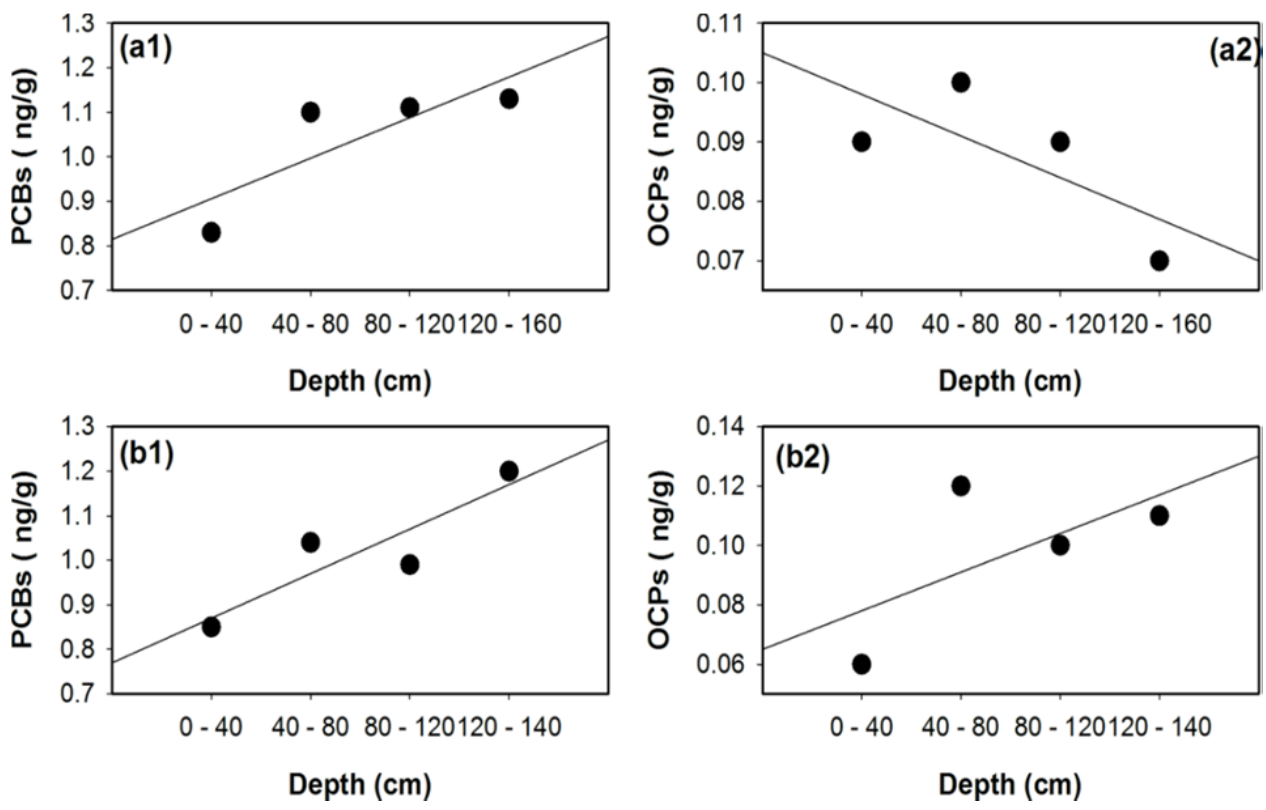

Figure 6. The variation of total PCBs and OCPs concentration with sediment depth from selected sampling sites in Ha Tinh - Quang Nam Sea (60-100 m water depth) (a1, 2 is a sample at $75 \mathrm{~m}$ water depth from the offshore Gianh estuary, b1, 2 is the sampling site at $62 \mathrm{~m}$ water depth from the offshore $\mathrm{An} \mathrm{Cu}$ gulf)

\section{Quality assessment of marine sediment and seawater environments}

National technical regulation on coastal water quality (MONRE, 2008) and National technical regulation on off-shore water quality -QCVN 44:2012/BTNMT (MONRE, 2012a) are used to access the seawater quality. The concentrations of $\mathrm{As}, \mathrm{Cd}, \mathrm{Pb}, \mathrm{Cu}, \mathrm{Zn}, \mathrm{Mn}, \mathrm{Hg}$, $\mathrm{Sb}$ were lower than the permitted values of QCVN44:2012/BTNMT (MONRE, 2012a), indicating the seawater environment from $\mathrm{Ha}$ Tinh - Quang Nam was not polluted by these metals (Table 5).

Interim sediment quality guidelines (ISQGs) (CCME, 2002) and National Technical Regulation on Sediment QualityQCVN 43:2012/BTNMT (MONRE，2012b) are used to access sediment quality. Results showed that the concentrations of $\mathrm{Cu}, \mathrm{Pb}, \mathrm{Zn}$, $\mathrm{Sb}$, As and $\mathrm{Hg}$ were lower than the permitted values of QCVN 43:2012/BTNMT and ISQGs, indicating that marine sediments from Ha Tinh - Quang Nam (60 - $100 \mathrm{~m}$ water depth) was not contaminated by above metals (Table 6 ).

Table 5. The average concentrations $(\mathrm{mg} / \mathrm{l})$ of selected metals in seawater of world, study area $(\mathrm{n}=804)$ and their permitted limit values by QCVN 10:2008/BTNMT and QCVN 44:2012/BTNMT

\begin{tabular}{|c|c|c|c|c|c|c|}
\hline \multirow{2}{*}{ Element } & \multirow{2}{*}{ World } & \multicolumn{3}{|c|}{ QCVN 10:2008 } & \multirow{2}{*}{ QCVN44:2012/BTNMT } & \multirow{2}{*}{$\begin{array}{c}\text { Ha Tinh - } \\
\text { Quang Nam Sea }\end{array}$} \\
\hline & & Beach & Aquaculture & Other & & \\
\hline$\overline{\mathrm{As}}$ & 0.003 & 0.04 & 0.01 & 0.05 & 0.005 & 0.00302 \\
\hline $\mathrm{Cd}$ & 0.0001 & 0.005 & 0.005 & 0.05 & 0.001 & 0.000172 \\
\hline $\mathrm{Pb}$ & 0.00003 & 0.02 & 0.05 & 0.1 & 0.005 & 0.000255 \\
\hline $\mathrm{Cu}$ & 0.003 & 0.5 & 0.03 & 1 & 0.01 & 0.00339 \\
\hline $\mathrm{Zn}$ & 0.01 & 1.0 & 0.05 & 2.0 & 0.02 & 0.0148 \\
\hline $\mathrm{Mn}$ & 0.002 & 0.1 & 0.1 & 0.1 & & 0.00262 \\
\hline $\mathrm{Hg}$ & 0.00003 & 0.002 & 0.001 & 0.005 & 0.000016 & 0.000036 \\
\hline $\mathrm{Sb}$ & 0.0005 & & & & & 0.0000428 \\
\hline
\end{tabular}


Vietnam Journal of Earth Sciences, 38(2), 217-230

Table 6. The average concentrations $\left(10^{-3} \%\right)$ of selected metals in marine sediments of world, study area $(\mathrm{n}=524)$ and their permitted limit values by ISQGs and QCVN 43:2012/BTNMT

\begin{tabular}{|c|c|c|c|c|c|c|c|c|}
\hline \multicolumn{2}{|c|}{ Pollution level } & Standard & $\mathrm{Cu}$ & $\mathrm{Pb}$ & $\mathrm{Zn}$ & $\mathrm{Sb}$ & As & $\mathrm{Hg}$ \\
\hline \multicolumn{2}{|l|}{ World } & & 4 & 2 & 2 & 0.14 & 0.1 & 0.003 \\
\hline \multicolumn{2}{|l|}{ Potential } & $>3 *$ TBTG & 12 & 6 & 6 & 0.42 & 0.3 & 0.009 \\
\hline \multirow[t]{5}{*}{ ISQGs } & Weak & $>\mathrm{Tel}$ & 1.87 & 3.2 & 12.4 & & 0.724 & 0.013 \\
\hline & Average & $>1.5 * \mathrm{Tel}$ & 2.81 & 4.8 & 18.6 & & 1.086 & 0.0195 \\
\hline & Strong & $>2 * \mathrm{Tel}$ & 3.74 & 6.4 & 24.8 & & 1.448 & 0.026 \\
\hline & Very strong & $>3 * \mathrm{Tel}$ & 5.61 & 9.6 & 37.2 & & 2.172 & 0.039 \\
\hline & Influence level & $>$ Pel & 10.8 & 11.2 & 27.1 & & 4.16 & 0.0696 \\
\hline \multicolumn{2}{|c|}{ QCVN 43:2012/BTNMT } & & 10.8 & 11.2 & 27.1 & & 4.16 & 0.07 \\
\hline \multicolumn{2}{|c|}{ Ha Tinh - Quang Nam Sea } & & 0.49 & 0.54 & 0.69 & 0.032 & 0.08 & 0.0056 \\
\hline
\end{tabular}

The concentrations of total OCPs and PCBs had not exceeded the TEL thresholds of ISQGs and were still lower than the permitted value of QCVN43:2012/BTNMT, indicating that the marine sediments of the study area were not polluted by OCPs and PCBs compounds.

\section{Conclusions}

Seawater is characterized by alkaline-weak oxidation and less effect by flows and activities from main lands and mainly contained of organic biodegradable materials. Surficial sediments of Ha Tinh - Quang Nam Sea (60-100 $\mathrm{m}$ in water depth) contained fineto coarse- grained size fractions. In which, the sediments with high absorbed capacity to toxic substances were mostly dominant and mainly distributed towards the northern study area. Sediment environment is characterized by weak alkaline - strong oxidation and rich in carbonate. The major anions and heavy metals in marine sediments highly concentrated in fine-grained size sediments. According to the seawater and marine sediment quality guidelines, the seawater and marine sediments of Ha Tinh - Quang Nam Sea had not been polluted by heavy metals, PCBs and OCPs compounds.

\section{Acknowledgements}

This paper was completed in the framework of the project "Investigation, integrated assessment and forecasting the variation of natural conditions, natural resources, envi- ronments and natural hazards from Thanh Hoa to Binh Thuan for implementing marine economic development".

\section{References}

Addo, M.A., Okley, G.M., Affum, H.A., Acquah, S., Gbadago, J.K., 2011. Water Quality and Level of Some Heavy Metals in Water and Sediments of Kpeshie Lagoon, LaAccra, Ghana. Journal of Environment and Earth Science, 3, 487-497.

Aderinola, O.J., Clarke, E.O., Olarinmoye, O.M., Kusemiju, V. and Anatekhai, M.A., 2009. Heavy metals in surface water, sediments, fish and perwinkles of Lagos Lagoon: American-Eurasian journal of agricultural \& environmental sciences, v.5, 5, 609-617.

Buccolieri A., Buccolieri, G., Cardellicchio, N., Dell Atti, A., Di Leo, A., Maci, A., 2006. Heavy metals in marine sediments of Taranto Gulf (Ionian Sea, Southern Italy). Marine Chemistry. 99, 227-235.

Carman, C.M.I., Xiang-Dong, L., Gan, Z., Onyx, W.H.W., Yok-Sheung, L., 2007. Trace metal distribution in sediments of the Pearl River Estuary and the surrounding coastal area, South China: Environmental Pollution, 147, 311-323.

Esslemont G., 2000. Heavy metals in seawater, marine sediments and corals from the Townsville section, Great Barrier Reef Marine Park, Queensland. Marine Chemistry 71, 3, 215-231.

Glasby, G. P., Schulz, H. D., 1999. Eh, pH Diagrams for Mn, $\mathrm{Fe}, \mathrm{Co}, \mathrm{Ni}, \mathrm{Cu}$ and $\mathrm{As}$ under Seawater Conditions: Application of Two New Type of Eh, pH Diagrams to the Study of Specific Problems in Marine Geochemistry. Aquatic Geochemistry, 5, 227-248.

Hedges, J. I., Clark, W. A., Cowie, G. L., 1988: Organic matter sources to the water column and surficial sediments of a marine bay. Limnology and Oceanography 33, 5, 1116-1136. 


\section{L. Huy, et al./Vietnam Journal of Earth Sciences 38 (2016)}

Majer A.P., Petti M.A.V., Corbisier T.N., Ribeiro A.P., Theophilo C.Y.S., de Lima Ferreira P.A. and Figueira R.C.L., 2014. Bioaccumulation of potentially toxic trace elements in benthic organisms of Admiralty Bay (King George Island, Antarctica). Marine Pollution Bulletin 79, 1, 321-325.

Mai Trong Nhuan, 2011. Survey on characteristics of geology, geodynamics, geological resources, geoenvironment and focasting geohazards of East Vietnam Sea from 30-100 m water depth, scale 1:500.000. Achieved in Marine Natural Resources - Environment Survey Center.

Naser, H.A., 2013. Assessment and management of heavy metal pollution in the marine environment of Arabian Gulf: A review. Marine Pollution Bulletin 72, 6-13.

Nguyen Bieu, 1999. Survey on geology and mineral resouces in nearshore East Vietnam Sea (0-30 m water depth), scale 1:500.000. Achieved in Marine Natural Resources Environment Survey Center.

Pham Van Thanh, 2009. Report on environmental geology map of marine sediments of East Vietnam Sea (0-20 m water depth), scale 1:250.000. Project No. KC09.21/06-10. Achieved in Ministry of Science and Technology.

Tran Nghi, 2004. Establishing the map of Quaternary formations of East Vietnam Sea and adjacent basin, scale 1:1.000.000. Project No. KC09-23. Achieved in Ministry of Science and Technology.

$\mathrm{Vu}$ Truong Son, 2004. Environmental geochemistry of neashore sea from Rach Gia-Vung Tau. Doctor disertation on Geology. Achieve in VNU University of Science.

Valavanidis, A., Vlachogianni, T., 2010. Metal pollution in ecosystems. Ecotoxicology studies and risk assessment in the marine environment. Sci. Adv. Environ. Toxicol. Ecot. Issues. chem-tox-ecotox. org/wp/wp-
content/uploads/2010/01/02-Metals-17_01_2010.

$\mathrm{pdf}$ [on line].

Vizzini S., Costa V., Tramati C., Gianguzza P., Mazzola A., 2013. Trophic transfer of trace elements in an isotopically constructed food chain from a semi-enclosed marine coastal area (Stagnone di Marsala, Sicily, Mediterranean). Archives of environmental contamination and toxicology 65, 4, 642-653.

Wang S., Jia Y., Wang S., Wang X., Wang H., Zhao Z., Liu B., 2010. Fractionation of heavy metals in shallow marine sediments from Jinzhou Bay, China. Journal of Environmental Sciences 22, 1, 23-31.

Canadian Council of Ministers of the Environment (CCME), 2002. Canadian sediment quality guidelines for the protection of aquatic life: Summary tables. Updated. In: Canadian Environmental Quality Guidelines, 1999: Canadian Council of Ministers of the Environment, Winnipeg.

Helsinki Commission and Baltic Marine Environment Protection Commission, 2004: Heavy metal pollution to the Baltic sea in 2004. Baltic Sea Environment Proceedings, No. 108.

Ministry of Natural Resources and Environment (MONRE), 2008. National technical regulation on coastal water quality - QCVN 10:2008/BTNMT.

Ministry of Natural Resources and Environment (MONRE), 2011. Guideline of quantifying and regulation on analytical results of geological and mineral samples.

Ministry of Natural Resources and Environment (MONRE), 2012a. National technical regulation on off-shore water quality - QCVN 44:2012/BTNMT.

Ministry of Natural Resources and Environment (MONRE), 2012b. National technical regulation on sediment quality QCVN 43 : 2012/BTNMT.

CCOP: http://www.ccop.or.th/Songthu Corporation: http://www.songthu.com.vn/ 